\title{
Transition metal carbonyl oestrogen receptor assay
}

\author{
Gérard Jaouen and Anne Vessières \\ Ecole Nationale Supérieure de Chimie de Paris (U.A. 403) \\ 11 Rue Pierre et Marie Curie, 75231 PARIS Cedex 05 - FRANCE -
}

\begin{abstract}
Hormonal steroids, such as 17 B-estradiol derivatives, TabelTed with organometallic moieties have been synthesized and tested as markers for hormone receptor assay. Among the organometallic labels used were $: \operatorname{Cr}(\mathrm{CO})_{3}$ and $\mathrm{Cr}(\mathrm{CO})_{2}(\mathrm{CS})$ which $\mathrm{Can}_{5}$ be attached to the arene $A$ ring of the steroid; $\mathrm{Co}_{2}\left(\mathrm{CO}_{6}\right.$ and $\mathrm{Mo}\left(\mathrm{n}^{5}-\mathrm{C}_{5} \mathrm{H}_{5}\right)_{2}(\mathrm{CO})_{4}$ which can be bonded to acetylenic groups introduced at the $17 \alpha$-position of the fjue-membered steroidal ring. There is a spectral window at about $2000 \mathrm{~cm}^{-1}$ in the FT-IR spectra of the protein precipitated from lamb uterus cytosol which we reasoned could be used to detect the $v(\mathrm{CO})$ modes of the metal carbonyl fragments of the organometallic labels. This indeed proved possible and the present detection level for 10,000-20,000 co-added scans at $4 \mathrm{~cm}^{-1}$ resolution is in the neighborhood of $100 \mathrm{fM}$. That specific rather than non-specific receptor sites were being detected was demonstrated by preparing an estradiol derivative doubly labelled with tritium and $\mathrm{Cr}(\mathrm{CO})_{3}$ and comparable receptor-site concentration levels were measured by both radiochemical analysis and FT-IR spectroscopy. The potential application of this new receptor assay technique in the early diagnosis of hormonedependent cancers appears feasible.
\end{abstract}

\section{INTRODUCTION}

Although the utility of transition metal carbonyl complexes in organic synthesis and industrial catalysis is now well established, their potential in biochemistry is only just being realized (ref. 1). Particularly, the biochemical importance of steroidal hormones which have been modified by the incorporation of organometallic moieties has only recently been appreciated (ref. 2). These species indeed show promise of unprecedented applications in the field of molecular biology in that they can function as markers in the study of receptors (ref. 2), are useful in immunology (ref. 3) and also serve as synthetic intermediates in regio - and stereospecific functionalisations (ref. 4). This promise is founded firstly on the ability of derivatives of hormones to recognize their specific receptor, and secondly on the strong absorptions of the metal carbonyl moieties in the infrared region 2100-1850 cm-1 ; this frequency range is compatible with a window in which the proteins do not absorb. This concept opens new vistas (e.g. an unprecedented use of such organometallic complexes in the field of steroid hormone receptor assay) whose full potential can hardly be ascertained at present. We note that this extension beyond the normal realm of transition metal complexes and into bio-organometallic chemistry has only become viable with the advent of Fourier Transform infrared techniques (FT-IR) which lowers the threshold of detection of so labelled hormones to the level of a few femtomoles per milligram of protein (ref. 2). This concentration corresponds to that commonly encountered in biological systems and so could be used to monitor the hormone dependance of breast cancer, Nevertheless, in spite of this enormous potential, there are still very few studies reported on these steroid complexes (ref. 5).

\section{MODEL OF STEROID HORMONE ACTION}

The steroids are a group of naturally occurring organic compounds and their synthetic derivatives, all of which are characterized by a basic skeleton consisting of three sixmembered rings and one five-membered ring (scheme 1). The intimate involvement of steroids in the cause of certain cancers (such as breast cancers) is now well established (ref. 6). Until 1984, there was general agreement that the following sequence of events takes place when steroidal hormones, such as oestrogens ( scheme 2), come in contact with a target cell : oestrogen enters the cell and interacts with specific receptor proteins in the cytoplasm, forming non covalent, high affinity complexes; the complex undergoes some change (activation) and translocates to the nucleus; it then interacts with nuclear 
component(s) and alters the pattern of gene expression. As a consequence of new protein synthesis induced by oestrogen, the target cell acquires new functional properties (ref. 7) (scheme 3)

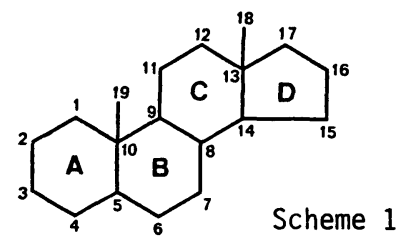

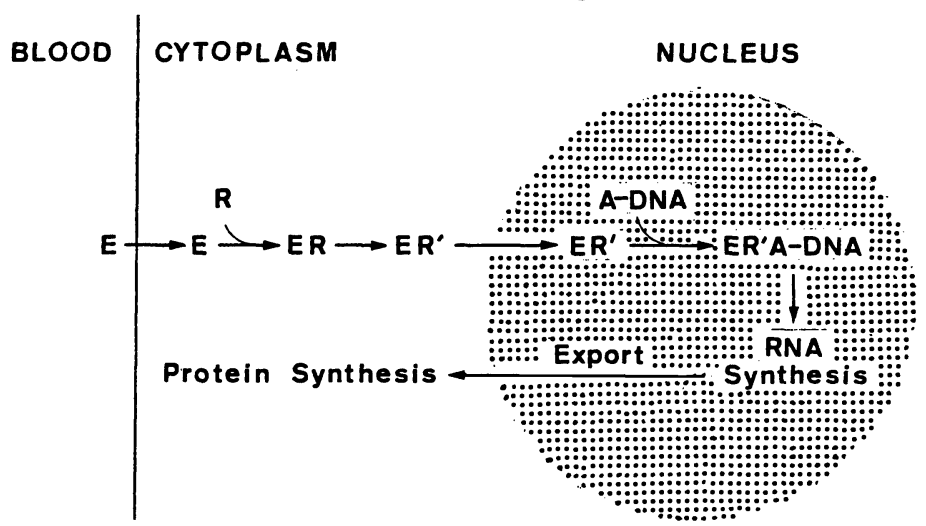<smiles>CC12CCC3c4ccc(O)cc4CCC3C1CCC2O</smiles>

Scheme 2. 1= 0estradiol the archetype of the oestrogens.
Scheme 3. According to the current model of steroid hormone action, oestrogen is thought to bind to its receptor in the cytoplasm of target cells and the oestrogen-receptor complex is then translocated into the nucleus ( ref. 8-10).

However, recent data (ref. 11) (ref. 12) suggest that the standard "two-step" model is an error and that the unoccupied receptor is nuclear in the intact cell. It is now proposed that there is no nuclear translocation of receptor as part of the steroid response, but rather an increase in receptor affinity for nuclear elements. In this new scheme, activation and reinforced nuclear binding would be concomitant. Whatever the true nature of steroid receptors, the basic mechanism of action remains valid; that is, high affinity and very stereoselective binding of the steroid to the receptor, followed by activation of the complex involving a modification in the DNA binding domain of the receptor protein. Consequently, it is not surprising that small alterations in the structure of certain oestrogensoften affect the receptor binding affinity of these compounds and their biological potency (for example, agonistic versus antagonistic response) (ref. 13). The simplified representation of the mechanism of action of $E_{2} R$ (oestradiol receptor) binding steroids is depicted in scheme 4 .

$0+$

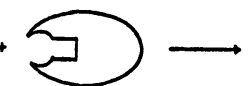

S (agonist)

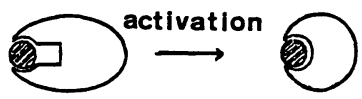

Activated complex

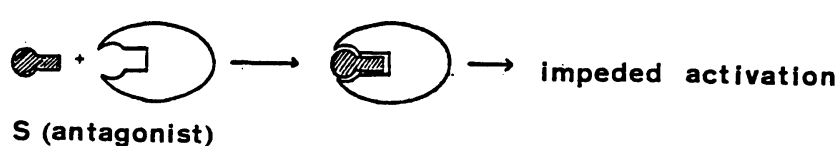

Scheme 4. Mechanism of action of $E_{2} R$ binding steroids.

S (antagonist)

\section{SYNTHESIS AND DETERMINATION OF THE ABSOLUTE CONFIGURATION OF THE COMPLEXED OESTROGENS}

The most straightforward way to mark estra-1,3,5(10)-trien-3, 17 -diol, 1, is to take advantage of the presence of the aromatic ring in the steroid. The attachment of a 12-electron moiety, such as $\mathrm{Cr}(\mathrm{CO})_{3}$, can occur on either the $\alpha$ - or $\beta$-face of the chiral molecule as shown in scheme 5 . By virtue of the dissymetric substitution pattern in the $A$ ring, this complexation generates planar chirality (ref. 14) and so a diastereomeric mixture results. For the synthetic and biochemical applications, it is of pivotal importance to establish the exact site of complexation in this series of molecules.

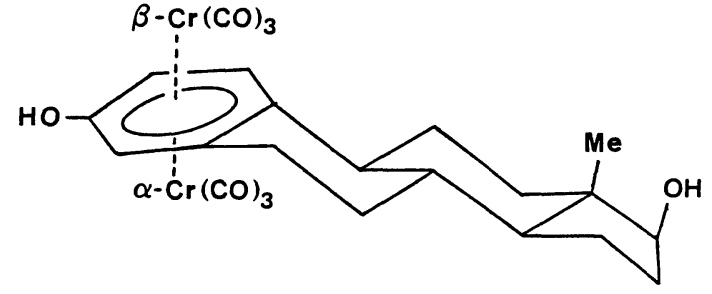

Scheme 5. The organometallic moiety can bind either to tne " $\alpha$ " or to the " $\beta$ " face of the hormone. 
The synthetic results are summarized in scheme 7 and show that the reaction of $17 \beta-$ oestradiol 1 with $\mathrm{Cr}(\mathrm{CO}) 6 y$ ields a diastereomeric mixture of 2 and 3 . Protection of the phenolic groups by incorporation of benzyl functionalities led to $\bar{a}$ diastereomeric mixture of 4 and 5. Following chromatographic separation of this mixture, each diastereomer was treated with sodium hydride in tetrahydrofuran and subsequently with tert-butyldimethylchlorosilane to give the doubly-protected oestradiol complexes 6 and 7 . The free doublyprotected oestradiol 8 is obtainable by simple photolysis in sunlight ${ }^{-}$(ref. 15).

Alternatively, one can silylate the phenolic substituent in 1 before complexation to give 9 ; subsequent reaction with hexacarbonylchromium (0) yields a díastereomeric mixture of 10 and 11 which may also be separated chromatographically. These latter two $\mathrm{Cr}(\mathrm{CO})_{3}$ complexes can be converted into their corresponding dicarbonylthiocarbonyl analogues, 12 and 13 , upon irradiation and reaction with $\mathrm{CS}_{2}$ (ref. 16). The monosilylated complexes 10 and 11 can be further silylated at the 17-position, to give 14 and 15; again the $\mathrm{Cr}(\mathrm{CO}) 3 \mathrm{moiet}$ is removable photochemically to yield the doubly-silylated oestradiol 16 (ref. 17).

In order to establish unequivocally the structure of one complex it was found that the most satisfactory crystals were those of the thiocarbonyl complex 12; X-ray crystallographic determination of the structure revealed that the thiocarbonyldicarbonylchromium tripod is attached to the $\alpha$ face of the steroid as depicted in scheme 6 .

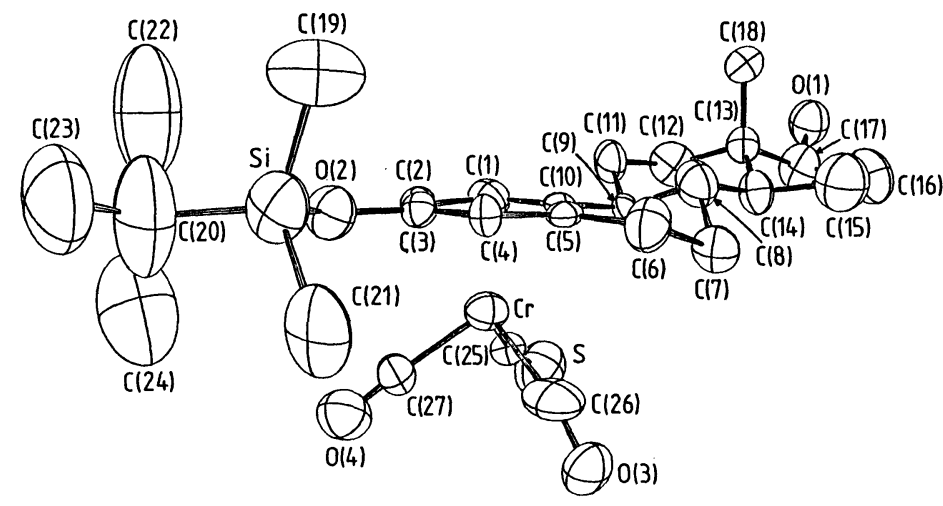

Scheme 6. An ORTEP view of complex 12 with $\mathrm{Cr}(\mathrm{CO})_{2} \mathrm{CS}$ attached to the $\alpha$ face of the molecule.

This immediately identifies 10 (the precursor of 12 ) as the $\alpha$-isomer; since 14 is merely the product obtained by a second silylation of 10 , this complex must have the same $\alpha$ configuration. The chemical correlation between the benzylated and silylated series of complexes was made by taking one of the non-protected oestradiol-Cr $(\mathrm{CO})_{3}$ complexes, 2 , and treating it with $\mathrm{NaH}$ and $\mathrm{t}-\mathrm{BuMe}_{2} \mathrm{Si} \mathrm{Cl}$ to give 10; subsequent photolysis and reaction with $\mathrm{CS}_{2}$ yielded a compound identical in all respects with 12 . Furthermore, benzylation of 2 gave the complex 4 and established all of these molecules as possessing $\alpha-C r(C 0)_{3}$ groups . Thus, the molecules numbered $\underline{3}, 5,7,11,13$ and 15 must be the $\beta$-isomers (scheme 7 ).

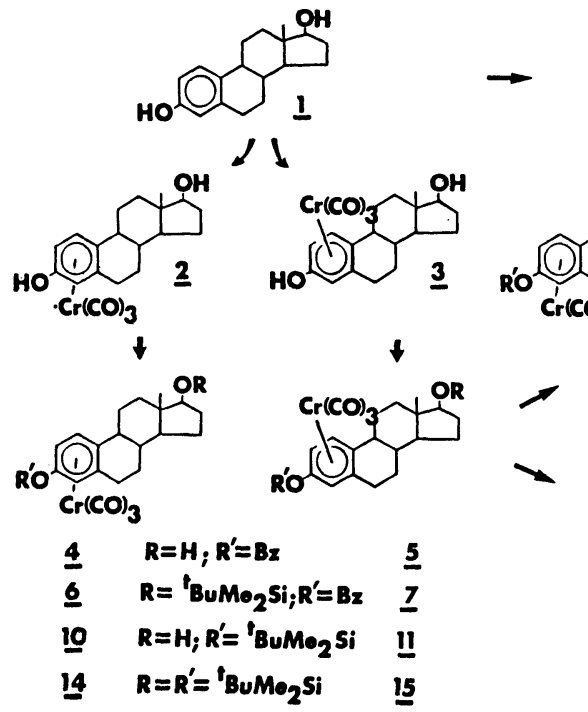

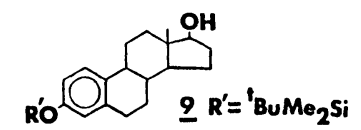
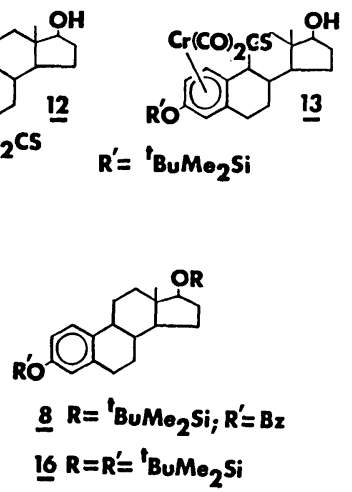

Scheme 7. Chemical correlation between the complexed oestrogens. 
Having established the absolute configurations of the molecules 2 through 15 , one can now examine the analytical methods available which, in principle, might be used to provide a relatively simple yet definitive means of differentiating between $\alpha$ - and $\beta$-complexes. At first sight, one might have visualized that the $\beta$-complexed molecules should be sterically disfavored because of non-bonded interactions between the tripod and the methyl group at $\mathrm{C}-13$; indeed, the behaviour of the $\mathrm{Cr}(\mathrm{CO})_{3}$ complexes of the methylindanes supports this idea (ref. 18). However, the relative yields of $\alpha$ - to $\beta$-isomers do not reflect the supposed importance of this steric effect. Thus, the experimental data (56:44 for $4: 5$ and $41: 59$ for $10: 11)$ reveal that the proportions of the diastereomers are inverted when one passes from one series to the other. Clearly, one cannot use such a criterion in these cases since it is difficult to know whether the reaction is thermodynamically or kinetically controlled. Furthermore, the incorporation of substituents which may interact competitively makes prediction difficult. Thus, 1-methylindane leads preferentially to the exo isomer (presumably for steric reasons), in contrast, 1 -indanol yields exclusively the endo configuration (ref. 14) (ref. 18). In oestradiol, however, these same two substituents are positioned contiguously on the $\beta$ face and the relative importance of these opposing effects is unpredictable.

Similarly, the specific rotation and the $\mathrm{Rf}$ values, as well as the infrared stretching frequencies of the carbonyl functionalities, do not permit accurate determination of the absolute configurations of these pairs of diastereomers.

However, an examination of the high resolution ${ }^{1} \mathrm{H}$ NMR spectrum of the $\left.\mathrm{Cr}(\mathrm{CO})\right)_{3}$ complexes of oestradiol and its derivatives allows ready differentiation of the $\alpha$ - and $\beta$-isomers.

Figure 1 shows the partial proton spectrum of 3 -benzyloxy-17 $\beta$-t-butyldimethylsiloxyoestra$1,3,5$ (ref. 10)-triene, 8, obtained at $500 \mathrm{MHz}$. Clearly, despite the chemical shift dispersion achievable at such magnetic field, overlapping resonances preclude the use of traditional assignment techniques. The strategy adopted in this study of oes utilizes some recently developed multi-pulse NMR techniques (COSY ; SECSY ; ${ }^{\mathrm{C}} \mathrm{C},{ }_{\mathrm{H}}$ heteronuclear chemical shift correlation (ref. 19)) to assign unambiguously each proton and carbon (ref. 17).

The $500 \mathrm{MHz}{ }^{1} \mathrm{H}$ spectra of the $\alpha$ - and $\beta$ - complexes, 6 and 7 , are presented in figure 1 . Again, peak overlap is a problem and has to be overcome vía a 2-D NMR experiment. The effects of complexation by $\mathrm{Cr}(\mathrm{CO})_{3}$ on the proton shifts of the steroid 8 exceeded our expectation and fully justified the effort expended in assigning all the peaks. The protons in the aromatic ring exhibited the approximately $2 \mathrm{ppm}$ shielding effect so typical of such systems (ref. 20). The most obvious and esthetically satisfying result is the clear differentiation of the $6 \alpha$ and $6 \beta$ protons. In the free arene, 8 , these two nuclei have almost identical chemical shifts while in the $\alpha$-complex the $6 \beta$ proton is shielded by $0.2 \mathrm{ppm}$ relative to $i$ ts partner; the $\beta$-complex shows a spectacular reversal and the chemical shift difference between these geminal protons is now more than half a ppm ! It is clear that the shielding of the protons distal to the $\mathrm{Cr}(\mathrm{CO})_{3}$ group and concomitant deshielding of the proximal protons is a consequence of the magnetic anisotropy of the tripodal moiety. More examples of shielded-deshielded nuclei with respect to the position of the $\mathrm{Cr}(\mathrm{CO})_{3}$ group can be found in the spectra of 6 and 7 , but a simple examination of the fingerprints of the 6 -protons signals ascertains the structure of the products of this diastereogenic complexation.

\section{DETECTION OF PHYSIOLOGICAL LEVELS OF HORMONAL STEROIDS LABELLED WITH ORGANOMETALLIC MARKERS BY FT-IR SPECTROSCOPY}

Some original features of transition metal organometallic hormones may provide novel applications of these derivatives beyond the field of organic synthesis. The important problem of protein receptor assay has been mainly based on a specific binding with a radioligand owing to the excellent detection properties of this technique (ref. 21) and in spite of some recognized disadvantages such as high cost of radioisotopes, health hazards, legal limitations, limited variety of useable isotopes, labelling difficulties, chemical and biochemical instability. These inconveniences have stimulated research into the feasibility of non-isotopic procedures for receptor assay (ref. 22).

In the infrared spectra of all proteins there is a spectral window at $2000 \mathrm{~cm}^{-1}$ and it occurred to us that the introduction of metal carbonyls as probe molecules might be a convenient way of monitoring certain biochemical processes since these compounds have extremely intense $\nu(C O)$ peaks in the $2150-1800 \mathrm{~cm}^{-1}$ region (ref. 23).

In principle, this simple concept may be of wide applicability. To illustrate our organometallic labelling/infrared spectroscopy approach, we have applied it to oestradiol receptor $\left(E_{2} R\right)$ for which the current methods of assaying utilize radiolabelled hormones (ref. 24). 

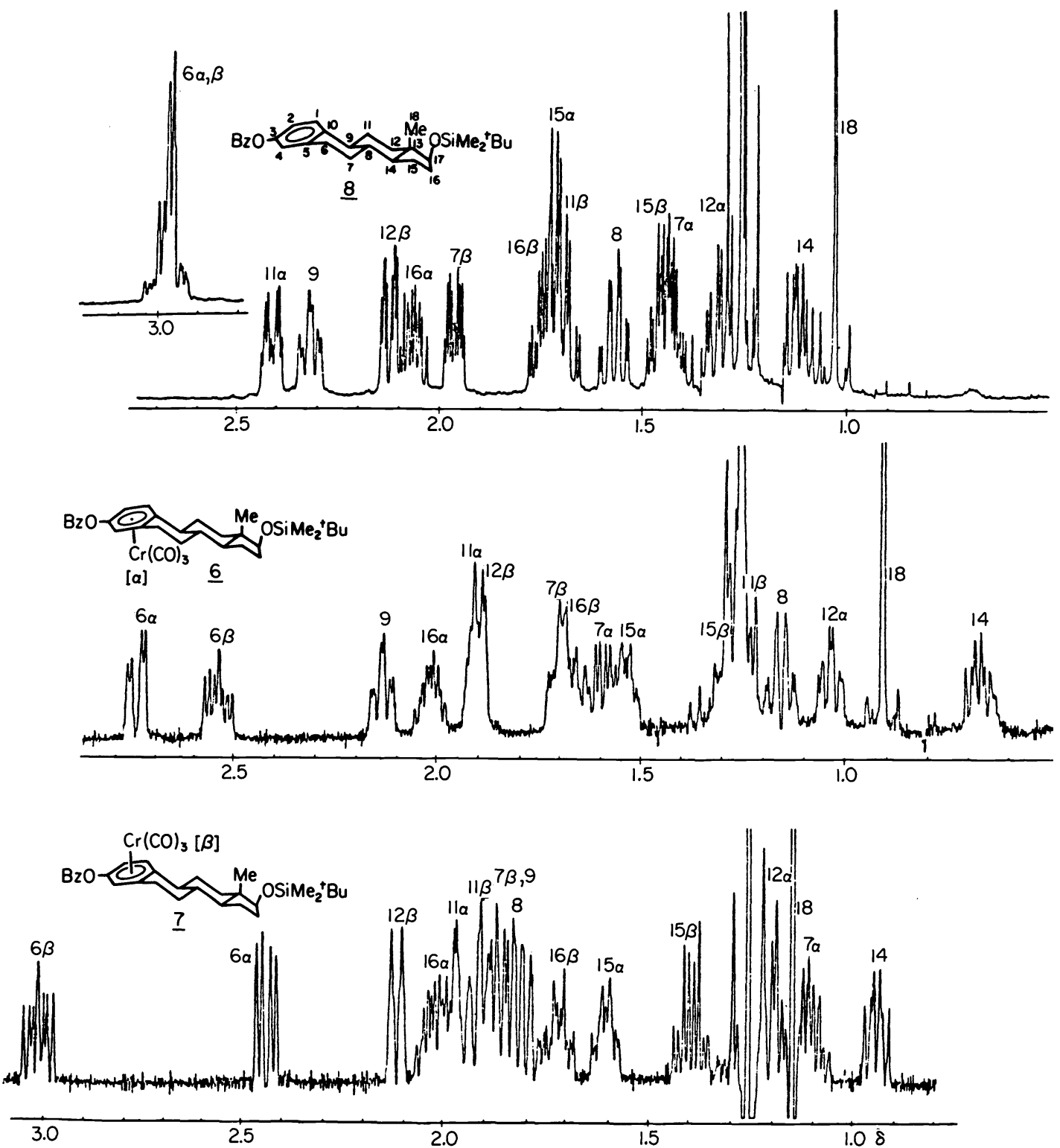

Figure 1. Sections of the $500 \mathrm{MHz}{ }^{1} \mathrm{H}$ NMR spectra of the molecules $\underline{8}, \underline{6}$ and $\underline{7}$

The first requirement to be met in the preparation of labelled hormones is, that the compounds be stable in solution and that they retain a high specificity for recognition of the relevant receptor. The present, highly-developed state of transition organometallic chemistry offers the opportunity to synthesize and exploit a rich and versatile new class of tailor-made metal carbonyl oestrogens. As shown before, an obvious site for complexation of oestradiol derivatives is the aromatic ring and the organometallic unit most compatible with such a six-electron ligand is the $\mathrm{Cr}(\mathrm{CO})_{3}$ moiety (ref. 14). Oestradiol derivatives without modification of the phenol function are unsuitable for our purpose since, after fixation of the $\mathrm{Cr}(\mathrm{CO})_{3}$ unit, these phenolic complexes rapidly decompose in solution giving rise to the free ligand and chromium salts. However, a modification of the 3-hydroxy function of the hormone results in complexes that are stable for years in the solid state and for several days in solution in the dark (scheme 7 ).

The binding affinities of the modified oestrogen complexes were determined by a competitive binding assay using tritium-labelled oestradiol as a tracer and lamb uterine cytosol as a source of oestradiol receptor. The relative binding affinity (RBA) of the competitors is taken as the ratio of the concentrations of unlabelled competitors required to inhibit half of the specific $(3 \mathrm{H})$-oestradiol binding with the affinity of oestradiol set at $100 \%$. 
TABLE 1. Receptor Binding Affinity of synthetized oestradiol derivatives.

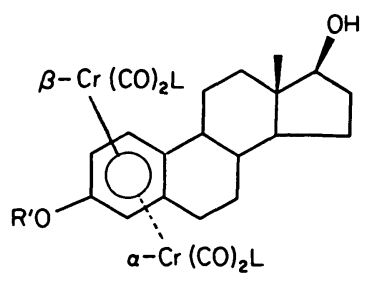

\begin{tabular}{|c|c|c|c|c|}
\hline Compound & $\begin{array}{c}\mathrm{I} \\
\mathrm{R}=\mathrm{H} \\
17 \beta \text {-oestradiol }\end{array}$ & $\begin{array}{c}\underline{9} \\
R^{\prime}=\left(\mathrm{SiCH}_{3}\right)_{2} \mathrm{tBu}\end{array}$ & $\begin{array}{l}\mathrm{R}^{\prime}=\mathrm{Si}\left(\mathrm{CH}_{3}\right)_{2} \mathrm{tBu} \\
\alpha-\mathrm{Cr}(\mathrm{CO})_{3}\end{array}$ & $\begin{array}{c}\underline{11} \\
\mathrm{R}^{\prime}=\left(\mathrm{Si} \mathrm{C \textrm {CH } _ { 3 }}\right)_{2} \mathrm{tBu} \\
\beta-\mathrm{Cr}(\mathrm{CO})_{3}\end{array}$ \\
\hline $\begin{array}{l}\text { Receptor } \\
\text { Binding } \\
\text { Affinity } \\
(\text { RBA) (a) }\end{array}$ & 100 (b) & 11 & 1.05 & 0.36 \\
\hline Compound & $\begin{array}{c}\underline{12} \\
\mathrm{R}^{\prime}=\mathrm{Si}\left(\mathrm{CH}_{3}\right)_{2} \mathrm{tBu} \\
\alpha \mathrm{Cr}(\mathrm{CO})_{2} \mathrm{CS}\end{array}$ & $\mathrm{R}^{\prime}=\mathrm{HO}\left(\mathrm{CH}_{2}\right)_{3}$ & $\begin{array}{c}\frac{18}{\mathrm{R}^{\prime}=\mathrm{HO}\left(\mathrm{CH}_{2}\right)_{3}} \\
\alpha-\mathrm{Cr}(\mathrm{CO})_{3}\end{array}$ & $\begin{array}{c}\underline{19} \\
\mathrm{R}^{\prime}=\mathrm{HO}\left(\mathrm{CH}_{2}\right)_{3} \\
\mathrm{~B}=\mathrm{Cr}(\mathrm{CO})_{3}\end{array}$ \\
\hline $\begin{array}{l}\text { Receptor } \\
\text { Binding } \\
\text { Affinity } \\
\text { (RBA) }\end{array}$ & 1.5 & 37 & 28 & 1.75 \\
\hline \multicolumn{5}{|c|}{$\begin{array}{l}\text { a competitive protein binding assay is a convenient method for determining } \\
\text { the binding affinity of modified oestrogens (ref. } 27 \text { ). To perform the } \\
\text { competitive binding assay lamb uterine cytosol was incubated at } 0^{\circ} \mathrm{C} \text { for } 3 \mathrm{hr} \\
\text { with } 2 \mathrm{nM} 6-7-3 \mathrm{H} \text { ] } 17 \mathrm{~B}-0 \mathrm{~s} \text { tradiol ( } \mathrm{S} . \mathrm{A} .52 \mathrm{Ci} / \mathrm{mmole} \text { ) and increasing amounts } \\
\text { of competing steroids ( } 10 \text { to } 1000 \text { fold excess). The bound fractions were } \\
\text { measured by protamine sulfate (ref. } 28) \text {. } \\
\text { b Values by definition. }\end{array}$} \\
\hline
\end{tabular}

In addition to having sufficient stability in solution, the modified oestrogen complexes were found to be effective in the competitive inhibition test, suggesting a favorable binding to the oestradiol receptor. Table 1 shows that, as previously quoted for other examples (ref. 25), substitution of the phenolic hydroxyl group invariably decreases receptor binding. However, a good affinity is regained when the 3-hydroxyl function is maintained away from the steroid skeleton by a spacer chain $\left(-0-\left(\mathrm{CH}_{2}\right)_{3}^{-}\right)$17. It appears also that the fixation site of the tripod on the A ring of the steroid strongly discriminates the $\alpha$ and $\beta$. diastereomers with respect to their recognition properties. While the $\beta$-isomers $(11,19)$ show relatively modest affinities, the $\alpha$-isomers $(10,12,18)$ bind with significantly higher ones. Among the complexes listed in Table 1 , compound $18\left(\mathrm{~m} . \mathrm{p} .130^{\circ} \mathrm{C}, \bar{\alpha}\right)^{22}=+41,7^{\circ}$ in $\mathrm{CH}_{2} \mathrm{Cl}_{2}$ solution, concentration $0.01 \mathrm{gml}^{-1}$; proved to be the most suitable for our purpose because of its long term stability in solution and its high receptor binding affinity $(R B A=28 \%)$, actually very close to that of the free ligand $17(R B A=37 \%)$. While for the $\mathrm{B}-\mathrm{Cr}(\mathrm{CO})_{3}$ analog 19 the RBA values is reduced to $1.8 \%$. Thus, one side of the $\mathrm{A}$ ring of the oestrogens can accomodate, by $\pi$-complexation, fairly large adducts. Such a hydrophobic pocket had never been envisaged before. Actually, the models for oestrogenic ligands binding to the oestrogen receptor are, up to now, rather primitive, as far as the stereochemistry of the association is concerned. Scheme 8 shows one of these recently proposed models (ref. 26).

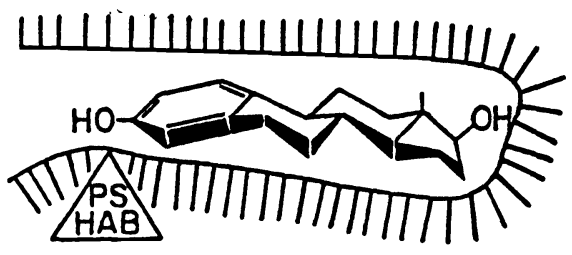

Scheme 8. Hypothetical model for oestrogenic ligands binding to the oestrogen receptor. Oestradiol $-17 \beta$ is anchored at the phenolic site (PS) with high affinity binding (HAB) (ref. 26). 
With labelled oestrogens used to measure the oestrogen receptor content of breast tumor samples, non-receptor binding can reduce the sensitivity of the assay procedure. In order to prove the specific association of the chromium-labelled steroids for the oestradiol

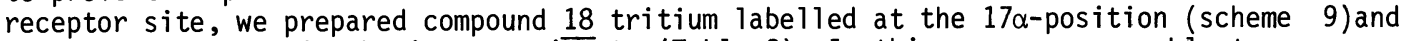
performed in vitro incubation experiments (Table 2). In this way, we were able to demonstrate that the radioactive hormone is bound specifically and reversibly to the uterine oestrogen receptor. Furthermore, the amount of nonspecific binding is only slightly increased when compared to that of $\left({ }^{3} \mathrm{H}\right)$-oestradiol itself. We also checked that compound 18 , as well as oestradiol, binds poorly to, and is not displaced by D.E.S. from highcapacity, low-affinity proteins found in non-target tissues (e.g.rat lung). That the organometallic label does not decompose during the binding experiment is indicated by the following Fourier Transform Infrared (FT-IR) measurements (ref. 30).<smiles>COc1ccc2c(c1)CCC1C2CCC2(C)[C@@H](O)CC[C@@H]12</smiles>

Scheme 9. $\left[17 \alpha-{ }^{3} H\right] 18$ was prepared from oestrone and showed a specific activity (S.A.) of $4.58 \mathrm{Ci} / \mathrm{mmole}$.

$T A \dot{B} L E$ 2. The radioactive hormone (conc. $\simeq 710^{-9} \mathrm{M}$ ) is bound specifically and reversibly to the oestrogen receptor. Non specific binding was determined by using a 500 fold excess of unlabelled DES (ref. 29)

\begin{tabular}{lccc}
\hline Ligand & $\begin{array}{c}\text { Round without } \\
\text { DES }\end{array}$ & $\begin{array}{c}\text { Bound with } \\
\text { DES }\end{array}$ & $\begin{array}{c}\text { Specifically } \\
\text { bound }\end{array}$ \\
\hline$\left[17 \alpha-{ }^{3} \mathrm{H}\right] \quad \frac{18}{\left[6,7-{ }^{3} \mathrm{H}\right] 17 \beta \text {-oestradiol }}$ & 918 & 149 & 769 \\
\hline
\end{tabular}

Based on the RBA values, most of the complexes listed in Table 1 should be useful for a receptor assay. The FT-IR spectrum of a lamb uterine cytosol incubated with oestradiol and precipitated by protamine sulfate shows a window just below $2,000 \mathrm{~cm}^{-1}$ (Fig. 2 and 3 ). In natural proteins, this situation is very general. The FT-IR spectrum of compound 18 is given in Fig. 4 ; the two $v(\mathrm{CO})$ peaks characteristic of the $\mathrm{C}_{3 v}$ symmetry $\mathrm{Cr}(\mathrm{CO})_{3}$ fragment are the strongest absorptions present. Similarly, the organometallic oestradiol derivative 10 exhibjts the two $\bar{\nu}(\mathrm{CO})$ modes of vibration of the $\mathrm{Cr}(\mathrm{CO})_{3}$ moiety at $1959.6 \mathrm{~cm}^{-1}$ (A1) and $1876.4 \mathrm{~cm}^{-1}$ (E) (Fig. 5). Next, in Fig. 6 , we show the FT-IR spectrum of the precipitated proteins following incubation with the organometallic tritiated compound 18 at approximately the same concentration $\left(\simeq 10^{-8} \mathrm{M}\right)$ as currently used in the radiochemical assays using oestradiol itself. The protein absorptions are off-scale owing to the thickness of the minipellet but two very weak features can be discerned above the backgroung at $\simeq 1900 \mathrm{~cm}^{-1}$. The computer expansion of this region shown in Fig. 7 reveals the two $\nu(C O)$ peaks of the organometallic marker. Similar results were obtained with all the chromium tricarbonyl labelled oestradiol molecules synthesized in this work; the example of 10 is depicted in Fig. 8. While the best signal-to-noise conditions for the spectra necessitated recording $10,000-30,000$ scans at $4 \mathrm{~cm}^{-1}$ resolution $(3-10 \mathrm{~h})$, the two metal carbonyl peaks can just be detected above the background at $8 \mathrm{~cm}^{-1}$ resolution in 2 min. These examples contain about 300 femtomoles of oestradiol receptor per mg of protein. This set of experiments establishes the feasability of a highly sensitive metal carbonyl oestrogen receptor assay.

In order to illustrate the effect of changing the point group symmetry of the organometallic label ( $C$ s instead of $C_{3}$ in 10 and 18) the final spectrum obtained for 12 is shown in Fig. 9. Two peaks are 6 Bserved at $1941 \mathrm{~cm}^{-1}\left(A^{\prime}\right)$ and $1884 \mathrm{~cm}^{-1}$ ( $\left.A^{\prime \prime}\right)$. The shifts in the $v(C O)$ peaks compared to the tricarbonyl derivative provide further evidence of complexation of the organometallic label to the receptor site,

There is an excellent correlation $(R=0.98)$ between the area of the higher-energy $\nu(C O)$ peak in the experiments with compound 18 and the weight of the minipellets (1-2mg) indicating that in principle it should be possible to extend this new method of protein receptor detection into the quantitative realm in the future (Fig. 10). 

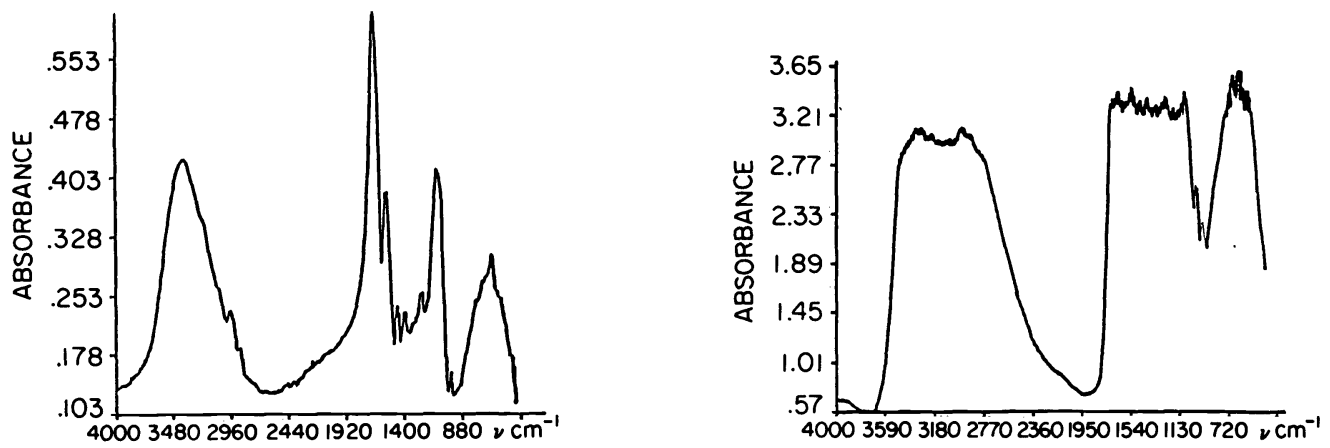

Fig. 2. FT-IR spectrum of lamb uterine cytosol. Fig. 3. FT-IR spectrum of lamb uterine cytofollowing incubation with 178-oestradiol and subsequent precipitation from solution with protamine sulfate (CsI minipellet). sol (same preparation as in Fig. 2; off scale; minipellet of the lyophilised precipitate).

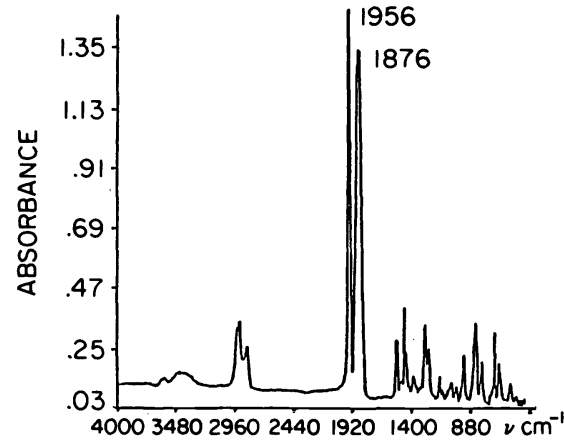

Fig. 4. FT-IR spectrum of compound 18 (CsI minipellet).

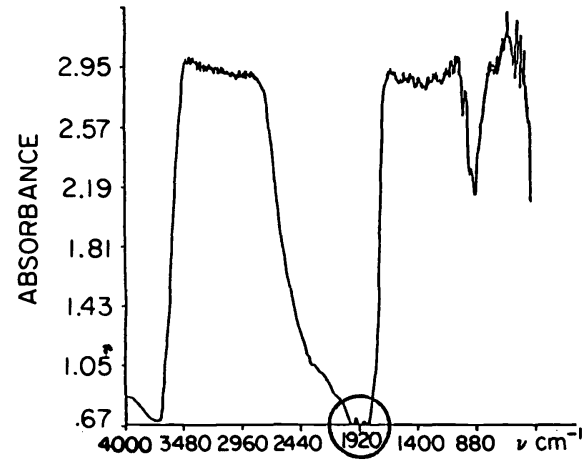

Fig. 6. FT-IR spectrum of lamb uterine cytosol following incubation with $[17 \alpha-3 H] 18$ and subsequent precipitation from solution with protamine sulfate (off scale, MCT detector).

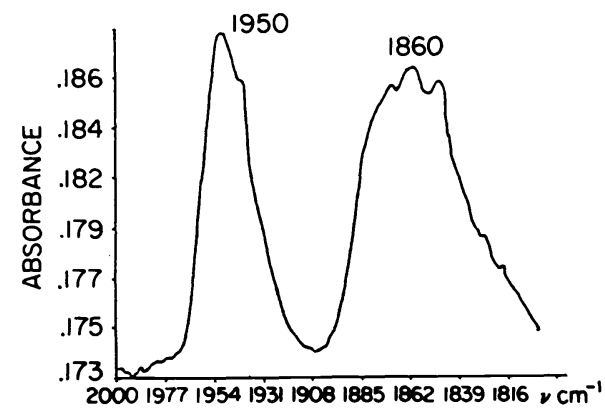

Fig. 8. Expansion of the metal carbonyl area of the IR-FT spectrum of lamb uterine cytosol incubated with compound 10, following baseline correction.

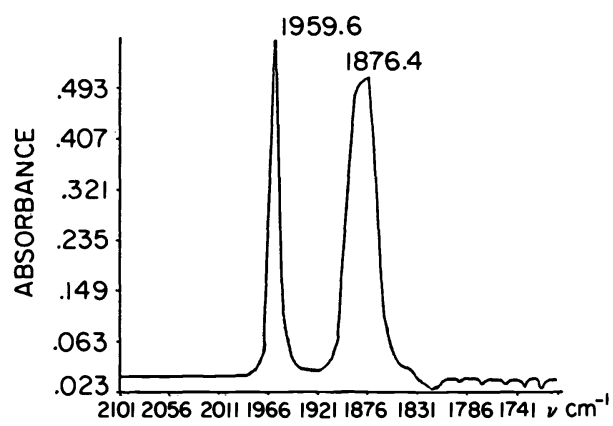

Fig. 5. $v(\mathrm{CO})$ section of FT-IR spectrum of compound 10 in benzene solution.

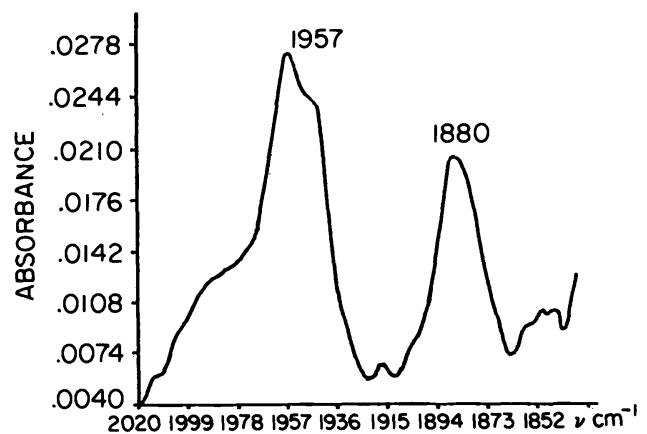

Fig. 7. Expansion of the $v(\mathrm{CO})$ region of the spectrum shown in Fig. 6 and base-line correction.

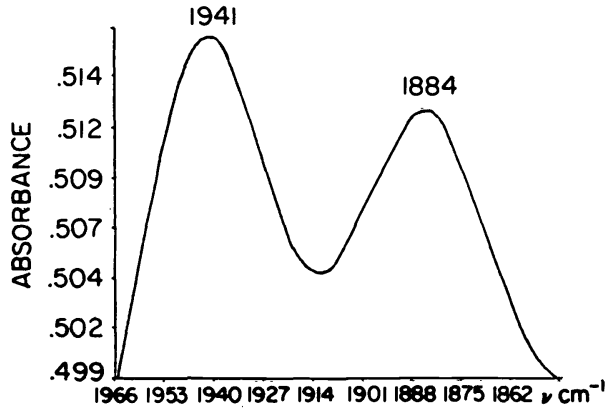

Fig. 9. Expansion of the metal carbonyl area of the FT-IR spectrum of lamb uterine cytosol incubated with compound 12 . 


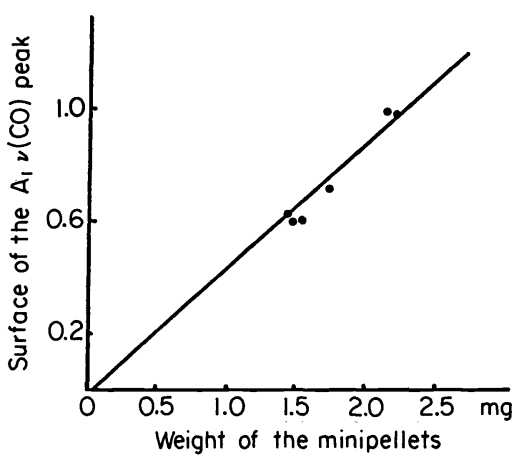

$\mathrm{Fig} \cdot 10$. Correlation $(R=0.98)$ between the weight of the minipellets and the surface of the $A_{1} \nu(C O)$ peak in compound 18 .

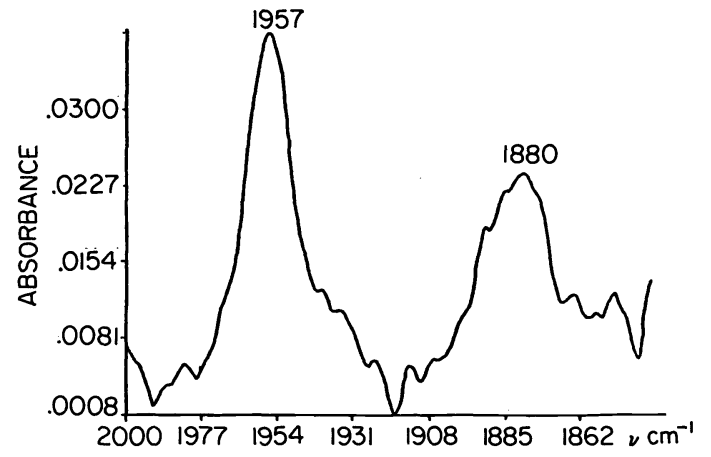

Fig. 11. FT-IR spectrum of the precipitated proteins following incubation with compound 21 (computer expansion of the $1850-2100 \mathrm{~cm}^{-1}$ region, lamb uterine cytosoll).

Hexestrol 20 offers distinct advantages over steroidal oestrogen derivatives : a higher binding affinity with respect to the oestradiol receptor and a simpler chemistry (ref. 31). The best obtainable complex in this series has been, so far, complex 21 for which a $2 \%$ $\therefore B A$ value was measured. According to Katzenellenbogen (ref. 27) compounds for which the affinity lies in the $0.5-5 \%$ range might be useful for labelling semipurified preparations of proteins and thus compound 27 could be a marker for oestradiol receptor detection. Fig. 11 shows the FT-IR spectrum of the precipitated proteins following incubation with compound 21 and establishes the potential use of hexestrol - $\mathrm{Cr}(\mathrm{CO})_{3}$ derivatives for oestradiol detection and assay (ref. 32).

Scheme 10. Hexestrol 20<smiles>CCC(c1ccc(O)cc1)C(CC)c1ccc(O)cc1</smiles>

Scheme 11. Complex 21<smiles>CCC(c1ccc(O)cc1)C(CC)c1ccc(OCO)cc1C(C)(C)C(=O)O</smiles>

The organometallic labelling is not, of course, limitated to the fixation of $\mathrm{Cr}(\mathrm{CO})$, units onto arene rings. For example, the possibility of modifying the $17 \alpha$ position of oestradiol by adding small clusters is depicted on scheme 12. These complexes 22 and 23 are stable in solution and show reasonable RBA vaTues (12-14\%). Therefore, metal carbonyl clusters can also be envisaged as markers in biochemistry.

Scheme 12<smiles>[R]C#C[C@]1(O)CC[C@H]2[C@@H]3CCc4cc(O)ccc4[C@H]3CC[C@@]21C</smiles><smiles>Ic1ccccc1</smiles>

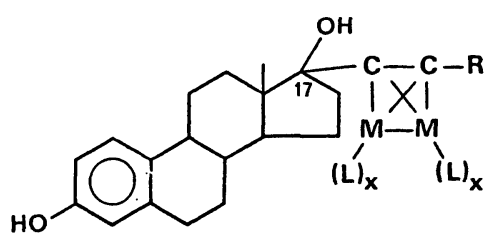

$$
\{
$$

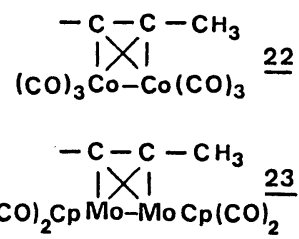

\section{CONCLUSION}

These results lead to the following conclusions : the detection limit of FT-IR appears to be as low as $10^{-12} \mathrm{~g}$ of metallic markers per mg of protein. This sensitivity satisfies the requirements for a receptor assay in contrast with other existing analytical methods for the detection of organometallic units such as atomic absorption or electrochemical techniques, for which the detection limits do not exceed $10^{-6} \mathrm{~g} \cdot 1^{-1}$ and $10^{-7} \mathrm{~g} \cdot 1^{-1}$ respectively. Moreover, the reasonably good specific binding properties obtained for our organometallic oestrogens differ strongly from the behaviour of synthetic fluorescent hormones which suffer from a high level of non specific binding. In addition to the above characteristics, the following advantages could also make metal carbonyl markers a useful al ternative to radioactive molecules in biological systems : a) ease of preparation, b) low cost, c) long-term stability of the complexes, d) rapidity of the measurements $(2-3 \mathrm{hr})$, e) predictable shape and positions of the $v(C O)$ signals (no artefact possible), f) compatibility with radio isotopic labelling agents (double labelling problems). Furthermore, the initial high costs associated with the purchase of an FT-IR spectrometer have decreased rapidly over the past few years, 


\section{ACKNOWLEDGEMENTS}

Efficient help of Siden Top, Ashraf Ismail, Ian Butler, Sylvie Tondu, M.Loüer, Monique Savignac, Michael Mc Glinchey is gratefully aknowledged, We also wish to thank Annie Cordaville for technical assistance and Marie-Françoise Amiache for typing the manuscript. This research was generously supported by operating grants for Bruker spectrospin (France), Roussel-Uclaf (France), C.N.R.S. and PIRMED (France), N.S.E.R.C. (Canada) and F.C.A.C. (Québec) and travel grants under the auspices of a France-Québec Exchange.

\section{REFERENCES}

1.a)H. Alper, Transition Metal Organometallics in Organic Synthesis ; Academic Press., New-York 1, (1976); 2, (1978).

b)S.G. Davies, Organotransition Metal Chemistry : Applications to Organic Synthesis ; Pergamon Press., London, (1980).

c)J.P. Collman, L.S. Hegedus, Principles and Applications of Organotransition Metal Chemistry; University Science Books ; Mill Valley., California, (1980).

2. G.Jaouen, A. Vessières, S. Top, A.A. Ismail, I.S. Butler, C.R. Acad. Sc. Paris Sér.II., $298,683(1984)$.

3. M. Caîs, L'Actuali ité Chimique., 7, 14 (1979).

4. G.Jaouen, S. Top, A. Laconi, D. Couturier, J. Brocard, J. Amer. Chem. Soc., 106, 2207 (1984).

5.a)G. Pouskouleli, I.S. Butler, J.P. Hickey, J. Inorg. Nucl. Chem., 42, 1659 (1980).

b) J.P. Hickey, I.S. Butler, G. Pouskouleli, J. Magn. Reson., 38, 501 (1980).

c) A.J. Birch, P.E. Cross, D.T. Connor, G.S.R. Subba Rao, J. Chem. Soc., C, 54 (1966).

d) R.W. Howsam, F.J. Mc Quillin, Tetrahedron Letts., 3667 (1968).

e) K. Henderson, F.J. Mc Quillin, Chem. Commun., I5 (1978).

f)B.M. Trost, T.R. Verhoeven, J. Amer. Chem. Soc., 102, 4743 (1980).

g)Y. Shimuzer, H. Mitsuhashi, E. Caspi, Tetrahedron Letts., 4113 (1966).

6. See for example, W.L. Mc Guire, Progress in Cancer Research and Therapy., 25, p.29 Raven Press, New-York, (1983).

7. G.A. Puca, V. Sica, N. Medici, A.M. Molinari, B. Moncharmont, A. Weisz, E. Nola, Pharmacological Modulation of Steroid Action., p.49, Raven Press, New-York, (1980).

8. E.V. Jensen, E.R. De Sombre, Science., 182, 126 (1973).

9. W.E. Stumpf, Endocrinology., 83, 777 (1968).

10. J. Gorski, B. Raker, EndocrinoTogy., 93, 1212 (1973).

11. W.J. King, G.L. Greene, Nature., 307,745 (1984).

12. W.V. Welshons, M.E. Lieberman, J. Gorski, Nature., 307, 747 (1984).

13. G. Teutsch, in Adrenal Steroid Antagonism., p.43 WaTter de Gruyter, Berlin, New-York (1984).

14. G.Jaouen, in Transition Metals in Organic Synthesis., 2, p.65-120, Academic Press, New-York (1978).

15. G.Jaouen, R. Dabard, Tetrahedron Letts., 1015 (1971).

16. G. Jaouen, G. SimonneauX, Inorg. Syntheses., XIX, 197 (1979)

17. S. Top, G. Jaouen, A. Vessieres, J.P. Abjean, D. Davoust, C.A. Rodger, B.G. Sayer, M.J. Mc Glinchey, submitted for publication.

18. D.E.F. Gracey, W.R. Jackson, W.B. Jennings, S.C. Rennison, R. Spratt, J. Chem. Soc., (B), 1210 (1969).

19.a)R. Benn, H. Günther, Angew. Chem. Int. Ed. Engl., 22, 350 (1983).

b) A. Bax, R. Freeman, J. Magn. Reson., 42, 164 (1981).

c) A. Bax, R. Freeman, J. Magn. Reson., 44, 542 (1981)

d)R. Freeman, G.A. Morris, Buil. Maan. Reson., 1, 5 (1979).

e)K. Nagayama, A. Kumar, K. Wüthrich, R.R. Erns $\bar{t}$, J. Magn. Reson., 40, 321 (1980).

f)W.E. Hull, Two-Dimensional NMR, Bruker Analytische Messtechnik, Karisruhe (1982).

20.a)L.F. FarnelT, E.W. RandalT, E. Rosenberg, Chem. Commun., 1078 (1971).

b) B.E. Mann, Chem. Commun., $976^{\circ}$ (1971).

c)B.E. Mann. J. Chem. Soc. Dalton Trans.. 2012 (1973)

d)B.E. Mann. Adv. Organometal. Chem., 12, 135 (1974).

e) M.M. Marica, J.S. Waugh, J.L. Fletcher, M.J. Mc Glinchey, J. Amer. Chem. Soc., 100,6902 (1978).

21. D.M. Barnes, G.G. Ribeiro, L.G. Skinner, Eu. J. Can., 13, 1133 (1977).

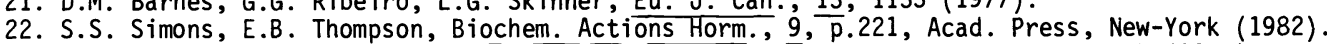

23. For example see : P. Braterman, Metal Carbonyl Spectra., Acad. Press, New-York (1975).

24. For example see : H.0. Hoppen, Estrogen Receptor Assays in Breast Cancer., p.141, Masson USA (1981).

25.a)F.J. Zeelen, E.W. Bergink, in Cytotoxic Oestrogens in Hormone Receptive Tumors.,p.39, Acad. Press, London (1980).

b) J.L. Witliff, N. Weidner, R.B. Everson, T.C. Hail, Cancer Treatment Reports., 62, p.1262 (1978).

c) G.A. Chernayaev, T.I. Barkova, V.V. Egorova et al. J. Steroid. Biochem., 6, 1483 (1975).

26. M.E. Lieberman, J. Gorski, V.C. Jordan, J. Biol. Chem., $258,47.41$ (1983).

27. J.A. Katzenellenbogen, H.J. Johnson Jr, H.N. Myers, Biochemistry., 12, 4085 (1973).

28. M.L. Thieulant, S. Samperez, P. Jouan, Endocrinology., 108, 1552 (1981).

29. R.B. Hochberg, Science., 205, 1138 (1979).

30. G. Jaouen, A. Vessieres, S. Top, A.A. Ismail, I.S. Butler, submitted for publication.

31. S.W. Landvater, J.A. Katzenel lenbogen, Mol. Pharmacol., 20, 43 (1981).

32. S. Tondu, S. Top, A. Vessieres, G. Jaouen, Chem. Commun,, 326 (ig85). 